\title{
JMI
}

\section{Perkembangan Kritik Terhadap Bank Islam: Tema, Substansi dan Respon.}

\author{
Memet Agustiar \\ Pengajar pada prodi ekonomi Islam FEB UNTAN: email: memet.agustiar@ekonomi.untan.ac.id
}

\begin{abstract}
ABSTRAK
Sebagai institusi keuangan, bank Islam tidak bebas kritis. Resistensinya diuji berdasarkan kadar kemurnian syariahnya. Penelitian ini bertujuan untuk mereview berbagai kritik yang ditujukan kepada bank syariah. Penelitian ini menggunakan metode kepustakaan dengan mereview tema kritik, subtansi, dan respon terhadap kritik. Penelitian ini mendapatkan bahwa tema dan substansi telah bergeser dari kritik bungkusan hingga ke substansi akad transaksi. Kritik-kritik tersebut dinilai bukan melemahkan eksestensi bank syariah, tetapi lebih merupakan upaya untuk makin memperkuat implementasi prinsip syariah pada perbankan syariah.
\end{abstract}

\section{PENDAHULUAN}

Pada awal kelahiraannya Bank Islam disambut dengan apresiasi dan tepuk tangan yang optimistik dari sebagian besar umat Islam. Perjuangan untuk mendirikan bank Islam terpacu oleh munculnya "bank kovensional" pertama pada tahun 1472 bernama Banca Monte dei Pashi di Siena, Italia. ${ }^{1}$ Hingga tahun 1900, wujud bank Islam bebas bunga hanya ${ }^{2}$ menjadi impian akademis belaka. Berbagai uji coba permulaan dimulai

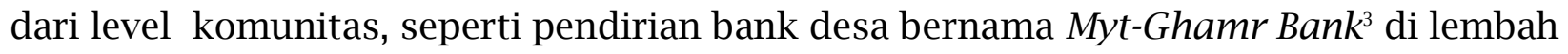
sungai Nil (Mesir) tahun 1963, umumnya gagal. Dua belas tahun kemudian (1975), barulah munculah bank Islam formal pertama di Dubai dengan nama Islamic Developmetn Bank, yang digagas oleh Organsasi Kerjasama Islam (OKI). Pelajaran ini menunjukan bahwa gagasan-gagasan besar dalam muamalah seringkali dimulai dari gagasan kecil yang bermula dari gerakan akar rumpuh (non-government organizationNGO), dan setelah itu secara bertahap baru ada respon formal dari pemerintah.

\footnotetext{
${ }^{1}$ Setelah itu muncul Berenberg Bank di Hamburg (tahun 1590), C. Hoare \& Co., di London (tahun 1672) dan Bank of New York di Amerika Serikat.

${ }^{2}$ Sekitar tahun 1940-an, di Pakistan dan Malaysia telah terdapat upaya-upaya pengelolaan dana jamaah haji secara non konvensional. Tahun 1963, Islamic Rural Bank berdiri di desa Mit Ghamr di Kairo, Mesir.

${ }^{3}$ Bank Islam Myt-Ghamr mendapat bantuan permodalan dari Raja Faisal Arab Saudi dan merupakan binaan dari Prof. Dr. Abdul Aziz Ahmad El Nagar. Namun karena persoalan politik, pada tahun 1967 Bank Islam Myt-Ghamr ditutup . Kemudian pada tahun 1971 di Mesir berhasil didirikan kembali Bank Islam dengan nama Nasser Social Bank, hanya tujuannya lebih bersifat sosial dari pada komersil
} 
Hari ini impian membangun bank tanpa bunga telah wujud dalam jumlah dan sebaran yang cukup banyak dan luas. Perkembangan lembaga keuangan syariah tidak hanya terbatas pada institusi keuangan (bank dan non-bank), tetapi terus meluas kepada keragaman produk, dukungan teknologi, regulasi dan kelembagaan. Di Ingeris lebih dari 70 universitas dan sekolah bisnis menawarkan program studi Islamic economic and banking dalam kurikulum formal mereka. ${ }^{4}$ Di Indoensia pada tahun 2020 tercatat ada sekitar 800 program studi ekonomi syariah yang ditawarkan di berbagai kampus di Indonesia (Kasri, 2021). Menurut Global Islamic Economic Report 2019-2020 (2021) total asset keuangan Islam mencapai USD 2.5 Trilyun, sementara bank Islam menguasai sekitar 19 \% pangsa pasar perbankan dunia. Malaysia berada pada peringkat pertama hampir di semua indikator ekonomi syariah dunia, dengan share perbankan Islam mencapai 20\% lebih. Di Indonesia sendiri, pangsa pasar keuangan Islam Indonesia baru mencapai 9,63\%, dengan total asset mencapai 545 Triyun. Jumlah bank syariah di Indonesia sebanyak 14 bank umum, 20 unit usaha syariah dan 163 bank perbiayaan rakyat (BPR) syariah. Secara umum, reputasi Indonesia dalam ekonomi syariah dunia berada pada peringkat empat, sebelumnya peringkat enam.

Di tengah kemajuannya yang cepat, bank Islam tidak bebas kritik. Kalau dulu kritik ditujukan untuk menghujah praktek bank kovensional yang tidak Islami dan bermuatan riba, kini kritik muncul dari dalam (internal critisms) yang menyoroti aspek kesyariahan bank Islam itu sendiri. Seberapa Islamkah bank Islam? Merupakan tema kritik yang dinilai makin mengemuka di pengujung dekade ini. Vadilo (2004) melahirkan buku mengenai tidak Islamnya bank Islam, setelah itu muncul karya ilmiah yang serupa dengan topik itu ditulis oleh Saqib (2010); Khan (2010) dan Saidi (2015).

Tulisan ini ingin mengidentifikasi, memetakan, dan menganalisis perkembangan kritik (tema kritik dan substansi) yang ditujukan kepada Bank Syariah mulai dari awal keberadaan bank syariah hingga saat ini. Metode yang digunakan dalam tulisan ini adalah studi kepustakaan (documentary research) dengan mencari sumber-sumber informasi yang terpercaya secara random. Tulisan ini terbagi dalam empat bagian. Bagian pertama adalah pendahuluan atau latar belakang, bagian kedua tentang apa itu kritik, bagian ketiga adalah pembahasan dan bagian ke empat berupa kesimpulan dan saran.

\section{APA ITU KRITIK}

Beberapa ahli mengungkapkan kritik mengandung analisis, interpretasi, evaluasi dan penilaian terhadap sebuah karya (Hill, 1966). Karena itu kritik adalah pertimbangan baik buruknya atas sebuah karya. Kritik mengandung tiga unsur penting yaitu (1) ada orang atau institusi yang bertindak sebagai pengkritik - disebut kritikus, (2) ada media yang menjadi objek kritik seperti naskah, pertunjukan, prilaku, produk dan sebagainya, (3) ada opini dari penilaian tersebut baik berupa ungkapan baik-buruk, setuju-menolak, ataupun netral.

Kritik bukanlah cara terakhir tanpa solusi. Respons terhadap kritik akan memberikan pemikiran berimbang menuju solusi bersama. Kritik sangat tergantung kepada

\footnotetext{
${ }^{4}$ Islamic Finance in the UK - Gov.ukhttps://assets.publishing.service.gov.uk > uploads > filePDF
} 
'kompetensi' kritikus agar lebih objektif. Semakin menguasai persoalan maka semakin dalam dan ilmiah kritik yang di lontarkannya. Namun demikian kritik juga tidak lepas dari unsur subjektifitas. Pengaruh emosional (latar belakang primordial dan identitas) bisa membawa ruang bias dalam kritik. Kritik rendahan (asal bunyi) bisa menjadi kurang berguna. Apalagi jika kritik didasarkan kepada kepentingan atau untuk sekedar mencari popularitas. Kritik juga bisa menjadi 'merek dagang' - yaitu membisniskan kritik karena ada pesanan khusus.

\section{PEMBAHASAN}

\section{Apakah bank Islam sungguh Islami}

Saqib (2010) adalah salah satu dari sekian banyak akademisi yang melontarkan pertanyaan mendasar terhadap bank Islam. Dalam artikelnya beliau mempertanyakan apakah bank Islam sungguh-sungguh Islam ('is Islamic banking really Islamic ?). Ada dua aspek yang menjadi sorotan beliau adalah soal metodologi perbankan dan soal penghapusan bunga. Pertama, apakah secara metodologi bank Islam dapat dibedakan secara jelas dengan bank konvensional, dan kedua, apakah bunga secara nyata telah dileyapkan dalam perbankan Islam. Kita tidak bisa membangun sistem perbankan Islam yang sempurna jika kita tidak memiliki sebuah perekonomian Islam yang benar (Saqib, 2010; Karimi, 2006).

Pada dimensi yang berbeda, Saidi (2015) lebih melihat tidak syariahnya bank Islam dari aspek mata uang yang dipakai, yaitu uang kertas. Sepanjang Dinar dan Dirham tidak dipakai dalam perekenomian maka sulit bagi kita untuk menyentuh esensi dasar kemurnian syariah. Interpretasi di atas tentu dilandasri oleh pemikiran bahwa hukum asal uang itu adalah halal. Uang adalah halal, tergantung cara menggunakannya apakah ada riba atau tidak. Jika uang itu haram maka otomatis tidak ada transaksi bisnis umat Islam sampai saat ini. Memang ada uang yang terbaik (the first best currency) yaitu Dinar dan Dirham, tapi ada juga yang terbaik ke dua (the second best) seperti fulus dan uang kertas. Walaupun banyak yang menolak kehalalan uang kertas, tetapi para ulama kontemporer membenarkannya sebagai mata uang dengan alasan kedaruratan.

Pernyataan ini benar, namun yang bersangkutan sangat menekankan kepada prasyarat dasar yang harus di penuhi. Artinya sistemnya dulu baik baru bisa bikin bank Islam. Pertanyaan mendasar adalah 'kapan' kita bisa mewujudkan system Islam yang benar dan kapan masyarakat bersedia mewujudkan gaya hidup (life-style) yang Islami. Jika jawabanya 'besok' maka 'lusa' kita sudah bisa bikin bank Islam. Jika 1000 tahun lagi, maka baru 1001 tahun kita bisa bikin bank Islam. Menurut pendapat penulis, 'bank Islam' bukan produk dari sistem yang sempurna terlebih dahulu (ex-ante), tetapi dia bisa terjadi setelah kemunculannya (ex-post). Dakwah telah dimulai sekalipun kondisi Mekkah waktu itu begitu jahil. Justru kekurangan system itu merupakan ladang tempur yang menantang untuk menegakan syariah. Bahasa ringkasnya: dandan sambil berjalan. Namun pada penghujung kritiknya (Saqib, 2010) mengatakan bahwa saya tidak hendak mengatakan bahwa kita harus menolak bank Islam, tetapi kita memerlukan gerakan yang lebih cepat untuk mengimplmentasikannya secara murni.

Temuan Khan (2010) menunjukan bahwa dalam tiga dekade terakhir, masih terdapat fungsi bank Islami yang secara tersembunyi memainkan peran seperti bank 
konvensional. Bahkan, untuk menangkis kritik itu mereka membungkus diri dengan terminologi Islam untuk produk-produk konvensional. Pandangan ini tidak keliru, namun tetap juga harus disadari bahwa bank Islam harus terlibat dalam persaingan dengan bank konvensional. Bank syariah harus bisa bertahan dan kompetitif, dengan tanpa mengorbankan syariahnya. Febianto \& Kasri (2007) memandang bank Islam cenderung bermain pada produk yang beresiko rendah (less risky trade-financing assets) dan jangka pendek (shoter manurity). Bank-bank itu cenderung menghindari pembiayaan mudharabah yang beresiko. Wajar kalau komposisi pembiayaan murabahah (jual beli) lebih dominan dari Mudharabah (bagi hasil).

\section{Nama Bank Islam.}

Banyak orang beranggapan bahwa bank Islam hanya ganti nama. Mengapa kita terlalu emosional pada 'bungkusan' (nama : bank Islam). Agaknya kepuasan emosional kita terpenuhi dengan nama bank Islam yang terpampang. Padahal, kita tidak mungkin menjual 'bir yang halal' sepanjang kita tidak mampu menemukan dalil yang membolehkannya. Bir yang dijual di toko pedagang muslim bukan berarti bir itu menjadi halal. Penulis menilai, penamaan Islam dan Syariah pada nama bank ini diperlukan, karena misi yang berkandung di dalam itu memberi ruang untuk mendakwahkan cara berniaga di sektor keuangan yang menjungjung prinsip fiqih muamalah (free interest economy).

Perdebatan tentang nama ini meluas ketika bank Indonesia (BI) lebih memilik menggunakan nomenklatur bank Islam (Islamic bank- iB) dari bank Syariah. Pengkritik mengatakan bahwa bank Islam terlalu universal, karena memuat sekaligus tiga dimensi yaitu Akidah, Akhlaq dan Syariah. Tetapi kalau menggunakan Syariah, maka lebih fokus tertuju pada aspek muamalahnya. Namun Bank Indonesia memandang lain, nilai jual di pasar komersial itu lebih melekat pada bank Islam (ada sekitar 226 juta pengunjung di google), sedangkan Sharia bank (ada 5,7 juta pengunjung), Bank Syariah (30 juta pengunjung). Walaupun ini bukan indikator yang terbaik, tetapi paling tidak bisa memberi signal akan kecenderungan user kepada penamaan tersebut. Dalam prakteknya, penggunaan kedua kata itu telah dapat diterima dan digunakan silih berganti dalam produk-produk keuangan dan perbankan. Sebagai contoh, penamaan program studi ekonomi syariah dan ekonomi Islam dipakai sama banyaknya di universitas dan institut. Bank-bank komerisl umumnya menggunakan istilah 'syariah' (BNI Syariah, Bank Syariah Mandiri, Bank Kalbar Syariah). Dengan penggabungan tiga bank plat merah pada tahun 2021 menjadi Bank Syariah Indonesia (merger BNI Syariah, BRI Syariah dan Bank Syariah Mandiri) makin meperkecil perdebatan pada aspek penamaan ini. Penulis menilai perdebatan nama ini menjaid kurang relevan sekarang ini.

\section{Rujukan kepada tingkat bunga (equivalent rate).}

Daya tolak yang cukup serius ditujukan kepada bank Islam adalah rujukan mereka dalam menentukan nisbah (\%) bagi hasil ataupun margin mudharabah yang dituduh mengacu kepada 'tingkat bunga' yang berlaku di pasar (equivalent rate). Rujukan kepada KIBOR (Kuala Lumpur Interbank Offer Rate) ataupun SIBOR (Singapore), dan LIBOR (London). Hal ini dituduh Saqib (2010) sebagai sebuah sistem yang bekerja di bawah sistem konvensional dengan cara memberi nama yang berbeda (nisbah, margin dan ujroh). 
Para pelaku perbankan syariah membela diri dengan menganggap equivalent rate (rate bagi hasil yang dituduh merujuk ke tingkat bunga umum) hanyalah sebuah prilaku dalam daya saing bisnis. Bank syariah harus menyadari bahwa ketika mereka masuk dalam pasar perbankan maka mereka berhadapan dengan sejumlah besar kompetiter dari perbankan konvensional. Oleh karena itu jika mereka menentukan nisbah bagi hasil terlalu rendah atau terlalu tinggi berbading rata-rata tingkat bunga yang berlaku di pasar maka mereka akan di tinggalkan konsumen. Pedagang awam di pasar tradisional juga harus memiliki strategi dalam menentukan harga jual, bukan pakai kacamata kuda tanpa melihat harga yang ditawarkan pesaing. Untuk memenangkan persaingan mereka harus memonitor (merujuk) setiap saat perkembangan harga yang memungkinkan mereka bisa meraih posisi dalam persaingan itu.

Menurut pendapat penulis, persoalan prinsipnya bukan pada nisbah bagi hasil yang besar atau kecil atau yang disetarakan dengan rate bunga yang berlaku umum, tetapi apakah akad yang digunakan sudah mengikuti prinsip-prinsip syariah. Sepanjang akadnya terjaga, maka kompetisi harga antar bank memang sebuah prilaku komersial yang harus terjadi.

\section{Pendapatan tetap (fixed income)}

Umumnya kritik utama yang ditujukan kepada bank Islam adalah penerapan hasil yang tetap (fixed income). Sebagai contoh produk ijarah atau sewa (Ijarah Muntahiya Bitamleek- IMB) di anggap banyak kalangan sebagai hal yang sama persis dengan sistem yang diterapkan dalam bank konvensional. Persamaanya adalah karena kedua bank tersebut, bank konvensional maupun bank Islam, sama-sama menarik pendapatan sewa secara tetap pada periode yang disepakati. Praktek menarik angsuran (pendapatan) secara tetap menjadi biasa pada akad jual beli (murabahah). Ini memang betul, karena murabahah sudah menetapkan 'margin (keuntungan) di awal, sehingga tidak lagi sesintif terhadap perubahan pendapatan dalam tahun berjalan. Jika akad mudharabah (bagi hasil), sensitifitas menarik pendapatan tetap ini memang banyak dipersoalkan. Oleh karena itu pada akad mudharabah, yang ditentukan di muka hanya 'nisbah (prosentasi para pihak) bukan nominalnya. Untung dan rugi tergantunga pada perhitungan laba rugi setiap bulan. Kerumitan ini membuat skema mudharabah kurang begitu di minati (dengan pertimbangan komersial) oleh bank syariah.

\section{System perbankan ganda (dual system bank)}

Banyak negara Islam menerapkan system perbankan ganda (dual banking system), seperti di Mesir, Qatar, Bahrin, Indonesia, dan Bangladesh. Beberapa negara, bank konvensional membuka 'Islamic window' atau mereka melengkapi produk konvensional mereka dengan menjual produk syariah seperti di Malaysia, Mesir, termasuk National Commercial Bank di Saudi Arabia. Demikian pula terdapat sejumlah bank Islam yang terdaftar di negara bukan Islam seperti Denmanrk, Luxembourg, Ingris, dan sekarang hampir di semua negara yang ada penduduk muslimnya. Di Sudan, Pakistan dan Iran mencoba menasionalisasi bank nasional mereka menjadi bank Islam. Gerakan menasionalisasi bank menjadi bank Islam ini sukses di Iran yang di dukung penuh oleh negara dan ulama (Sani, 1994).

Keberatan banyak orang menganai bank Islam juga ditemukan pada dualisme system perbankan. Dalam system perbankan di tanah air, Bank Mandiri Syariah (sebelum merger) memiliki dua platform, syariah dan konvensional dalam satu holding Bank 
Mandiri. Biasanya bentuk dua banking system ini adalah melalui saluran Unit Usaha Syariah (UUS), di mana bank konvensional memiliki unit khusus yang syariah. Sahamnya full dari bank induknya yang masih konvensional. Sebagai contoh, Unit Usaha Syariah yang ada di Bank-Bank Pembangunan Daerah di Indonesia. Pada tahun 2017, Bank Aceh telah melakukan konversi menjadi bank Syariah yang merupakan bank pembangunan daerah dengan platform syariah pertama di Indonesia. Hanya Bank Muamalat sebagai bank syariah pertama yang muncul tidak dari bank konvensional.

Kritik terhadap pola dua system bank ini adalah soal sumber penyertaan saham atau modal dasar dari Unit Usaha Syariah. Selain itu bagaimana mungkin satu sisi bank menjual produk syariah dan sisi lain bank menjaul produk konvensional dalam satu gedung perbankan seperti yang banyak terjadi di Malaysia. Jawaban untuk ini merujuk kepada status akad. Tidaklah menjadi soal dari manakah sumber permodalan yang diperoleh, karena semua dana yang masuk ke bank syariah akan melalui pentahapan 'screening' dengan mengikuti cara akad syariah. Ketika sumber pendanaan masuk ke bank syariah maka aturan permainanya sudah mengikuti cara syariah. Akad akan membuat dana-dana itu menjadi 'mualaf' (menjadi Islami). Sejauh ini bank islam menerima tabungan dari nasabah non-muslim, dibenarkan oleh Fatwa DSN-MUI. NO: 02/DSN-MUI/IV/2000 tentang Tabungan.

\section{Bank sebagai pedagang (Murabahah versus Mudharabah)}

Beberapa keberatan tentang bank Islam muncul juga dalam konteks bank yang bertindak sebagai pedagang terutama dalam akad murabahah (jual beli). Dalam akad jual beli tersebut, posisi bank mulanya sebagai penyedia dana (funder), kemudian merubah dirinya menjadi penyedian barang (seller), dan kemudian mewakilkan posisinya kepada nasabah untuk membeli barang yang dia inginkan. Setelah itu nasabah mengembalikan posisi perwakilannya kepada bank kembali, dan kemudian terjadilah akad jual beli. Jual beli itu menggunakan pola pembayaran dengan cicilan oleh nasabah kepada bank.

Bank dibenarkan bertindak sebagai mudharib (penyandang dana) dan juga dibenarkan melakukan fungsi 'perwakilan' (wakala) dalam jual beli (murabahah) sesuai dengan Fatwa Dewn Syariah Nasional (DSN MUI No :04/DSN-MUI/2000). Fungsi mewakalakan tugas bank kepada nasabah adalah fungsi bank sebagai pedagang, dan kedudukan inilah yang banyak di kritik oleh berbagai pihak. Badri (2008) mengatakan satu sisi bank bertindak sebagai fund manager, sebagai tempat menyimpan uang ketika berhadapan dengan para penabung, namun kemudian bertindak sebagai pemodal ketika berhubungan dengan investor. Beliau mengatakan "akad yang dilakukan bank selama ini adalah akad hutang piutang dan bukan mudharabah'. Namun beliau juga mengatakan bahwa bank boleh melakukan usaha kedalam usaha yang nyata (tidak begitu jelas apakah yang dimaksud adalah sector riil), untuk mendapatkan hasil. Bank tidak boleh menyalurkan modal yang ia terima dari pemodal dalam bentuk akad mudharabah. Sehingga, bila ia berperan sebagai pemodal, maka ini mendustakan kenyataan yang sebenarnya, yaitu sebagin besar dana di kelola adalah milik nasabah.

\footnotetext{
${ }^{5}$ Badri, Arifin Muhammad (2008) seorang ustadz kandidat Doktor Fakultas Syariah Universitas Islam Madinah) di muat dalam Majalah As-Sunnah Edisi 06-07/THN. XII/Ramdhan 1429 H - September 2008, Halaman 23-29. Judul : Mencari Solusi Bank Syariah.
} 
Kritik Badri (2008) ini menarik untuk dikaji. Pertama, beliau menegaskan bank hanya boleh sebagai tempat menitipkan uang (withdrawing function) saja. Bank tidak dibenarkan untuk menyalurkan dananya ke masyarakat, karena dana tersebut adalah dana nasabah. Skim ini mirip atau lebih cocok pada tabungan wadiah (hanya untuk menitipkan uang). Kalaulah begitu, maka kedudukan bank sebagai fund manager akan menjadi terbatas, karena fungsi intemediarinya akan terpasung. Namun sekarang ini dalam akad wadiah sekalipun, bank boleh menarik manfaat (berupa ujroh), dan dibenarkan juga mengelola dana wadiah jika mendapat persetujuan dari nasabah.

Penulis menilai, bank tidak boleh melakukan kegiatan ganda terkesan kaku. Di dunia yang serba terbuka, sulit membatasi satu instiitusi keuangan untuk berperan pada satu tugas saja. Tugas fund manager itu banyak dan melibatkan berbagai pihak . Memang kalau bank menjalakan tugas diluar kompetensinya seperti sebagai pedagang tentu kepasitanya akan terbatas. Tetapi ini adalah sebuah rekayasan akad dalam jual beli, yang memberi ruang bagi siapa saja yang memerlukan pembiayaan dalam jual belinya secara cicil. Jika tidak, akan sulit dicari institusi atau individu yang bersedia menyediaan dana untuk pembiayaan dalam jual beli.

\section{KESIMPULAN}

Penelitian ini mendapatkan bahwa kritik-kritik yang ditujukan kepada bank syariah telah bergeser dari kritik bungkusan (kritik permukaan) kepada kritik yang substantial (merujuk kepada akad dan kemurnian syariah). Hal ini sangat penting, karena bagimanapun kritik terhadap akad inilah yang menentukan kualitas kesyariahan sebuah bank syariah. Namun kita harus menyadari bahwa bank syariah hidup dalam lingkungan bisnis yang kompetitif. Ia harus juga memposisikan dirinya sebagai pemain dengan sejumlah besar pesaing dari bank-bank konvensional. Memang banyak rekayasa akad, namun rekayasa bukan hal terlarang, sepanjang itu tetap berjalan dalam koridor syariah. Munculnya kontrak hybrit, kartu kredit Syariah (Syariah card - fatwa DSN fatwa DSN No.54/DSN-MUI/X/2006) merupakan contoh di mana rekayasa produk itu semakin dinamis.

Intinya keberatan dan penolakan terhadap bank Islam dalam peradaban Islam dewasa ini adalah bermuara dari tidak adanya contoh mengenai institusi perbankan dalam masyarakat Islam pada jaman Rasullualh SAW dan seterusnya. Tetapi 'praktekpraktek' transaksi keuangan yang di jalankan pada masa itu mengandung unsur-unsur yang menjadi fungsi bank dewasa ini. Bank menyimpan uang, maka pada masa itu ada orang yang menitipkan uang pada seseorang. Bank melakukan fungsi pengiriman dan penukaran, maka pada masa itu telah pula terjadi pengiriman uang dan penukaran. Jadi tugas dan fungsinya sama hanya bungkusannya beda. Kalau dulu dibungkus dengan pendekatan personal, kalau sekarang di bungkus dengan pendekatan intitutional.

Tetapi dibalik itu semua, keraguan, pertanyaan, dan lebih keras lagi penolakan masih terus saja ada. Mengapa demikian? Karena semua orang ingin ambil bagian di dalam membangun peradaban muamalah yang betul (syariah). Mereka perduli, karena mereka ikut bertanggungjawab. Muamalah adalah bagian dari keseharian kita. Mata uang, berbelanja dan berproduksi serta menabung adalah kegiatan yang selalu wujud dalam masyarakat Islam. Kita seharusnya sepakat bahwa tidak ada umat Islam yang anti 
muamalah. Karena 'muamalah' adalah sebuah topik penting baik dalam Al-Qur'an, maupun dalam risalah Hadist. Ayat mengenai muamalah menguasai tiga per empat dari Al-qur'an. Paling tidak ada 70 ayat yang membicarakan soal muamalah (ekonomi). Bahkan ayat yang paling panjang di Al-Qur'an menyangkut ayat tentang hutang piutang (al-Baqarah: 286 terdiri dari : 128 kata dan 504 huruf).

Anehnya semakin kuat kritik terhadap bank syariah, makin memperkuat posisinya di tengah dunia perbankan dunia. Sedikit sekali bukti bank Syariah yang bangkrut. Namun perlambanan pertumbuan bank syariah nampaknya terjadi di mana-mana. Kritik menjadi peringatan dini (early warning system) bagi semua bank syariah untuk kembali ke rel syariah, agar tidak terbawa arus kompetensi yang mengorbankan prinsip kesyariahan.

\section{DAFTAR PUSTAKA}

Badri, Arifin Muhammad (2008) Mencari Solusi Bank Syariah. Majalah As-Sunnah, Edisi 06-07/THN. XII/Ramdhan 1429 H - September 2008, Halaman 23-29.

Febianto, I., \& Kasri, R. (2007, July). Why do Islamic banks tend to avoid profit and loss sharing arrangements?. In 2nd Islamic Economics Conference.

Global Islamic Economic Report 2019-2020 (2021). Foundation report 2020. https://wief.org/

Hamoud, S.H (1994) Progress of Islamic Banking: TheAspiration and the Realities'. Islamic Economic Studies, 2 (1) , pp. 71-80.

Hill, K.C. (1966). Interpreting Literature, Chicago: The University Press of Chicago.

Karimi, Abdul Jabbar (2006). Challenges facing Islamic banks.navailable at: http://www.nzibo.com/IB2/Challenges.pdf

Kasri, R, (2021). Revitalisasi Kurikulum Pendidikan Ekonomi Islam di Indonesia. Makalah di presentasikan pada Workshop Revitalisasi Kurikulum Prodi Ekonomi Islam, FEB UNNTAN, 4 Desember 2021, Pontianak.

Khan, F. (2010). How 'Islamic'is Islamic banking?. Journal of economic behavior \& organization, 76(3), 805-820.

Majeed, Muhammad Tariq, and Abida Zainab. "How Islamic is Islamic banking in Pakistan?." International Journal of Islamic and Middle Eastern Finance and Management (2017).

Saidi, Z. (2015). Tidak Syariahnya Bank Syariah. Yogyakrta: Delokomotif.

Saqib Omer Saeed (2010). Is Islamic banking really Islamic ?. The Express Tribune Blog. www.bizomer.com , Http://blogs.tribune.com.pk/story/ 194. 9/30/2010.

Vadillo, U. I. (2004). The Return of the Islamic Gold Dinar: A Study of Money in Islamic Law \& the Architecture of the Gold Economy. Madinah Press. 